Artigos

\title{
Liderança Política: Virtù e Parresía
}

Silvana Maria Corrêa Tótora'

Miguel Chaia ${ }^{2}$

Resumo Trata-se da relação entre ética e política e suas ressonâncias na constituição e atuação da liderança política. Consideramos a ação política vinculada ao personagem que a empreende num jogo de relações de poder agonístico, relativo à disputa, luta e conflito. Selecionamos do pensamento de Maquiavel o conceito de virtù e os estudos de Foucault sobre a parresía na democracia ateniense da Antiguidade. Esperamos introduzir a noção de parresía no debate atual da liderança política.

Palavras chave: Democracia; liderança política; ética; pensamento político.

\section{Political leadership: Virtú and Parresía}

Abstract This text is about the relationship between ethics and politics and its resonances in the constitution and action of the political leadership. We consider political action linked to the character that engages the action in a game of relations of agonistic power, related to dispute, struggle and conflict. We selected in the thought of Machiavelli the concept of virtù and the Foucault studies on parresía in athenian

\footnotetext{
1 Departamento de Política e Programa de Estudos Pós-Graduados em Ciências Sociais da Pontifícia Universidade Católica de São Paulo (PUC-SP) - São Paulo - Brasil - silvanatotora@gmail.com

2 Departamento de Política e Programa de Estudos Pós-Graduados em Ciências Sociais da Pontifícia Universidade Católica de São Paulo (PUC-SP) - São Paulo - Brasil - mwchaia@pucsp.br
} 
democracy of Antiquity. We hope to introduce the notion of parresía in the current debate of the political leadership.

\section{Keywords: Democracy; leadership; ethics; political thinking.}

Os períodos da Antiguidade clássica dos atenienses (século $\mathrm{V}$ a. C) e o Renascimento Italiano (séculos XV e XVI), em que pesem suas diferenças, configuram-se em momentos de grande fortuna e invenções de novas possibilidades da política. Em comum, caracterizam-se pela quebra da ingerência de poderes externos à atividade política. Grandes personagens fizeram de suas realizações individuais e artísticas uma obra de arte e, com isso, gravaram seu nome na história (Burckhardt, 1991).

O homem político faz sua entrada em meio à política como um jogo incessante de relações de forças conflituosas, num regime agonístico. E a atividade política se move nesse jogo sem garantias prévias, seja de uma ordem natural que realiza a "boa sociedade", seja de valores morais validados pelo costume ou por instâncias transcendentes que dirigem a ação.

A potência da política dos períodos selecionados advém, de um lado, da não configuração de um poder político como instância separada da coletividade e instituído de modo a assegurar esta separação. Referimo-nos à inexistência de um Estado estruturado em sua conformação de poder soberano. Por outro lado, não se configura na pólis democrática ateniense (século $\mathrm{V}$ a. C.) uma dominação fundada na divisão assimétrica e antagônica na coletividade dos cidadãos (Arendt, 1999; Castoriadis, 1987).

Isto posto, consideramos profícuo para um estudo da emergência da liderança política esses dois momentos da história, tomando por base os conceitos de virtù no O Príncipe, de Maquiavel, e o de parresía, estudado por Foucault. Em ambos os conceitos está presente um êthos político que passa longe da compreensão moral como código de condutas de valores universais que guiam o agir político. A Virtù e a parresía, como veremos a seguir, vinculam-se à potência do agir em meio ao jogo conflituoso de relações de forças. A veracidade do agir parresiasta está longe de uma concepção de verdade universal, assim como o homem de virtù não se posiciona como um agente da moral, pelo contrário, ele a desafia.

\section{A virtù como a arte do governo em Maquiavel}

Maquiavel inaugura o pensamento moderno com um conceito do êthos político distinto dos pensamentos antigo e medieval. Pode-se afirmar que, para o 
autor, a virtù presta-se a superar os problemas colocados pela fortuna e também possibilita ampliar a realização do projeto do príncipe, além de sedimentar a honra e a glória deste governante. Assim, conforme Michel-Pierre Edmond (1993), a virtù não é redutível ao cálculo racionalista ou a uma estratégia política, mas trata-se de um exercício da liberdade. Esta qualidade não designa o meio para tomar o poder e conservá-lo, mas ela é um fim em si mesmo, suficiente enquanto energia própria ao príncipe.

A virtù, para Maquiavel, não se reduz a uma tecnologia de poder que movimenta uma estrutura estatal com função estratégica dominante. Isto porque, em $O$ príncipe, governo e stato se confundem, e, além disso, ambos estão na dependência das habilidades e da liberdade do príncipe em lidar com as circunstâncias. A razão de Estado como centralidade do pensamento filosófico configura-se, no nosso entender, no século XVII, particularmente com Hobbes. Para esse filósofo, a análise do governo se faz em termos da soberania do Estado.

Maquiavel delimita simultaneamente dois campos de fluxos políticos: por um lado, recorta a esfera do político com suas características específicas e próprias e, por outro lado, considera a virtù como uma propriedade colocada no homem para avançar em novas direções políticas e implementar projetos elaborados no interior das circunstâncias históricas.

Nesta direção, o capítulo XXV de $O$ Príncipe é bastante elucidativo ao afirmar que a fortuna seja árbitra da metade das nossas ações, mas que a virtù é responsável pelo restante das possibilidades. Por isso, é melhor ao príncipe ser impetuoso do que dotado de cautela. A virtù possibilita que o príncipe se defronte com a fortuna e, simultaneamente, dê vazão às qualidades ou às energias que são próprias do homem em ação. Portanto, há uma especificidade no agir político do príncipe ao se considerar a virtù, pois supõe um gasto de energia potencializadora da ação, do cálculo e da estratégia selecionada.

Assim, imbuído da virtù e ampliando o conceito de liderança, pode-se pensar o príncipe como um líder inovador e fundador na esfera política, elaborando um projeto significativo fora do âmbito das instituições. $\mathrm{O}$ príncipe novo em Maquiavel desafia as leis e os costumes tradicionais (cap. VI). O príncipe se move em meio ao perigo e ameaças permanentes ao seu governo não só dos poderosos, mas do conjunto dos súditos que não desejam ser oprimidos e querem mudar de governo na esperança de melhorar. Daí a habilidade pessoal do príncipe em reunir meios da fortuna e da virtù para um governo razoavelmente seguro. Dizemos razoavelmente porque o príncipe se move em meio a relações conflituosas da parte dos poderosos que ambicionam a sua posição e da resistência criativa do povo. 
O termo virtù remete à capacidade de um homem agir para conquistar e manter o poder político, sob duas circunstâncias relacionáveis ou não entre si. Primeiro, ao expressar e implementar um projeto político na forma inovadora das leis e costumes vigentes. E, segundo, como fundador de um stato utilizando-se de uma série de recursos para conquistar os súditos, assegurando a continuidade do mando. Assim, a virtù deve ser entendida como qualidade própria do homem agindo politicamente, afastada de questões morais, e que aliada à fortuna, permite as melhores possibilidades do êxito político, ainda que não haja garantia.

Para Maquiavel, se as coisas do mundo podem ser governadas pela fortuna, não basta acompanhar a sorte, como deixa explicitado no capítulo XXV de $O$ Príncipe. A capacidade ou a qualidade política encontra-se na ação que consegue articular as coisas do mundo contra os fluxos torrenciais do acaso. A virtù potencializa os homens a tomarem providências, enfrentarem o presente e pensarem o futuro, organizando-se contra o ímpeto desenfreado das forças do acaso. Se a fortuna permite a complementação da virtù, esta, por sua vez, expande a política pela proposição (calculada) de novos experimentos.

A virtù não deixa de exigir um ato corajoso, vinculando-se a si mesmo na práxis de ações arriscadas em meio às forças contrárias. A virtù é um exercício voluntarioso de liberdade. Mas teria este ato corajoso o mesmo sentido que parresía? Em parte, quando se trata de um ato arriscado que desafia os valores de uma moralidade da conduta externa ao jogo político. Contudo, a parresía política é o dizer-a-verdade numa democracia de autogoverno dos cidadãos, pondo em risco a sua pessoa que não teme contrariar os valores da maioria. O príncipe arrisca a sua pessoa para ascender e se manter no governo. São riscos de natureza diferente, pois, em relação à virtù maquiaveliana, a franqueza parresiasta pode gerar a perda do governo.

A ética maquiaveliana traduz-se num ato arriscado e livre, está contida na figura do príncipe de virtú, impetuoso, combativo e audacioso. A política pode-se fazer como um exercício de risco e, no interior desta possibilidade, fazer com que o âmbito da política se amplie e inove pela ação de um condottiere que inventa soluções e reúne a multiplicidade dispersa num povo sob comando ou sob governo. Assim, a virtù é, simultaneamente, forma de conhecimento e esforço ativo que permite ao príncipe agir com retidão nas circunstâncias frente às necessidades.

Conforme o capítulo XVIII de O Príncipe, trata-se de maximizar as ações políticas, utilizando-se bem tanto das leis quanto da força animal. No combate político um príncipe deve saber bem empregar o animal e o homem, não 
deixando escapar de sua boca nada que não seja repleto das qualidades do governante. O príncipe deve ser realmente piedoso, fiel, humano, íntegro e religioso - caso não possua algumas destas qualidades, deve aparentar possuí-las. Há uma dissociação entre a fala e as ações do príncipe que simula e dissimula valores. Neste caso, ele age como um retórico que faz uso dos valores em benefício de seu governo. E se necessário for, age contrário aos valores morais que se reputam como orientadores do agir. Nesse sentido, a virtù e a parresía, como veremos a seguir, se distinguem.

A virtù em Maquiavel está presente no corpo do príncipe, manifestando-se na ação do sujeito envolvido com a ação política. Corpo e gestos, domínio do cálculo e enfrentamento das circunstâncias e da fortuna estão fundados na virtù e configuram-se em qualidades de um homem no agir político que busca o poder ou a conservação do poder, facilitando estas atividades políticas. O corpo do governante "virtuoso" permite maior coincidência com o corpo do povo "virtuoso". Tais observações podem ser detectadas não só n’O Príncipe, mas também em Comentários sobre a Primeira Década de Tito Lívio (1979), principalmente nos capítulos quinquagésimos do Livro Primeiro; nestes capítulos, Maquiavel trata da autoridade de um homem respeitado para conter a multidão excitada e da multidão ser mais sábia e constante do que o príncipe. Por isso, a República romana (dos séculos V ao I a. C) é vista por Maquiavel como um sistema político portador de grandes virtudes políticas, supondo-se assim uma correspondência com a presença corporal de um príncipe virtuoso.

Em Maquiavel é importante a presença do corpo do governante virtuoso e do povo republicano, na direção proposta por Isaiah Berlin (2000), para quem "as bênçãos da era clássica poderão ser restauradas (se a fortuna não for muito contra) por um volume suficiente de conhecimento e vontade, por virtù por parte de um líder, e por cidadãos apropriadamente treinados e conduzidos com bravura e habilidade" (Ibid.: 22).

\section{Parresía e liderança políica}

A década de 1980, dentre outros acontecimentos, foi atravessada por um intenso debate sobre a democracia (Tótora, 1998) que mobilizou os intelectuais de diferentes correntes de pensamento. Emergiram, também, organizações populares e lutas sociais contra os regimes autoritários tanto na Europa quanto na América Latina. Na esteira desses movimentos e ideias vinha também uma ácida crítica aos regimes socialistas do leste europeu. Travou-se, nesta época, uma disputa em torno do sentido da democracia. 
Em seu curso de 1983, O governo de si e dos outros, Foucault se insere no fluxo deste debate, deslocando sua análise para a Antiguidade, especificamente para o período da vigência da democracia direta dos atenienses dos séculos $\mathrm{V}$ e IV a. C. Dentre as inúmeras questões políticas suscitadas na ocasião, Foucault, livre de vínculos doutrinários, destaca a atuação ética dos indivíduos na política com base na pesquisa do termo antigo parresía. Com suas pesquisas, espera explicitar a relação da filosofia com a política, assim como contribuir com a discussão da democracia na atualidade 3 . Longe de uma adesão ou rejeição da democracia, Foucault a problematiza ${ }^{4}$. E sua leitura dos antigos irá ajudá-lo a problematizar o êthos político.

Antes de darmos início à explicitação da relação entre parresía e democracia na Antiguidade, cumpre-nos situar a pertinência atual deste debate no contexto desse início de século XXI. Diferentemente da adesão, nos anos 1980, ao regime da democracia representativa, as revoltas e mobilizações urbanas que se alastram há mais de uma década em todo o Ocidente atestam uma profunda rejeição aos políticos, sejam eles eleitos pelo método democrático ou não. As democracias rotinizaram a seleção de seus "líderes" mocráticos (disputa partidária em eleições livres), mas sobre eles pesam inúmeras críticas, desafiando as análises que faziam da apatia política o maior perigo das democracias. E mais, as críticas incidem contra os que governam independente de serem escolhidos por métodos democráticos ou antidemocráticos.

Estaríamos diante de um esgotamento de uma política de representação com base na liderança profissional, segundo o conceito de Max Weber? A esse status somam-se o descrédito dessas "lideranças", advindo do alto grau de corrupção, decorrente do uso do cargo político para a defesa de interesses próprios ou por favorecimento de grandes grupos econômicos. Corrupção, baixa qualidade política compreendida no âmbito do interesse público, perda da confiança

3 Neste curso, Foucault situa a relevância de sua pesquisa sobre a relação entre democracia e parresía na Antiguidade para a época atual. De acordo com ele, "numa época como a nossa em que se gosta de colocar os problemas da democracia em termos de distribuição do poder, de autonomia de cada um no exercício do poder, em termos de transparência e de opacidade, de relação entre sociedade civil e Estado. Talvez fosse interessante recuperar a questão do discurso verdadeiro e da cesura necessária, indispensável e frágil que o discurso verdadeiro não pode deixar de introduzir numa democracia" (Foucault, 2010: 170).

4 Em 1981, os franceses elegeram um presidente do Partido Socialista, François Mitterand, apoiado pelo Partido Comunista Francês. Para Foucault, no entanto, não cabe ao intelectual ou ao filósofo avalizar as ações do governante, e, tampouco, dizer aos políticos o que eles tem que fazer. Sua atuação se destaca como pesquisador, e não como porta voz dos que estão diretamente envolvidos nas relações de poder.

5 A utilização das aspas coloca a utilização do termo sob suspeita. 
dos eleitores, dentre outros fatores, denotam a falência de um modelo de representação política liberal democrática que há mais de um século vem sendo alvo de críticas, mas também defendido e praticado.

Finley $(1988)^{6}$ se posiciona criticamente em relação à concepção predominante da democracia moderna, particularmente, a redução do seu significado por Schumpeter (1984) como método de escolha dos governantes. Para o primeiro, o poder de tomar decisões é adquirido por meio da disputa dos partidos pelos votos do eleitorado. O problema, para Finley, reside no fosso que se abre entre, por um lado, as decisões dos governantes e, por outro, a passividade dos governados. Os primeiros governam livres da corresponsabilidade produzida por uma participação ampla dos cidadãos. A participação dos governados limita-se às eleições Segundo esse autor, a teoria da democracia de Schumpeter carrega uma herança das teorias elitistas de Mosca, Pareto e Michels. Nessa linha, a liderança política seria exercida por uma elite protegida da pressão das massas, ou da participação ativa daqueles que não têm a responsabilidade direta pelo exercício do governo. Os líderes dos partidos decidem pelo povo. Schumpeter difere dos demais elitistas no que tange à adoção do método democrático de escolha da elite que exercerá a liderança política em nome de todos.

Finley (1988) critica, nos anos 1970, o predomínio da concepção de democracia representativa enunciada por Schumpeter (1984) e se posiciona a favor da democracia direta da Antiguidade. Neste texto podemos inferir a defesa de uma concepção de liderança fortemente vinculada aos liderados, conforme praticada pelos atenienses, e não, como ele denomina, com base na época atual, de "falsos líderes" medíocres e manipulados por trás da cena (Finley, 1988: 37). Na democracia dos atenienses, o reconhecimento da liderança não implicava a renúncia ao poder decisório. A liderança era direta, pessoal e responsável perante a assembleia dos cidadãos. O líder aconselha, enfrenta outras posições e as decisões são tomadas e assumidas em conjunto com todos os cidadãos reunidos.

$6 \quad$ Finley (1988: 17-53) discorre comparativamente sobre a democracia ateniense dos séculos V e IV a. C. e a democracia representativa dos anos 1970.

7 Na mesma direção de Schumpeter, afirma Lipset (apud Finley, 1988: 25): "o elemento característico e mais valioso da democracia é a formação de uma elite política na luta para disputar os votos de um eleitorado em sua maior parte passivo". 
Numa abordagem diferente, Foucault $(2010 b)^{8}$ vai além da crítica circunscrita à democracia representativa moderna, ele refere-se a uma "crise de governo" na atualidade, mais explicitamente de uma "crise de governamentalidade".

Não basta contentar-se com a afirmação sobre a existência, no presente, de uma crise de governo. Cumpre, por sua vez, precisar os efeitos de poder dessa crise $^{10 .}$ De acordo com Foucault, as relações de poder ou exercício de governo produzem saberes ou verdades. Foucault (2010a) recupera dos gregos o termo aleturgia, cujo significado diz respeito ao conjunto de procedimentos de manifestação da verdade. Esse termo é empregado para todo o exercício de poder que se realiza pela enunciação da verdade. Segundo Leme (2008: 184-185), com o emprego desse termo Foucault pode desvencilhar-se da dicotomia entre verdade e poder e desenvolver a ideia de "governo pela verdade" e, com isso, realizar um deslocamento do eixo do poder para o êthos.

Leme (Ibid.) chama a atenção para as colocações de Foucault (2001), no seu curso Os anormais ${ }^{11}$, para o uso do grotesco, do ridículo, do infame, de certos personagens políticos como um dos procedimentos essenciais ao exercício de governos arbitrários. Esses personagens que Foucault denomina de "ubuescos", ao invés de desqualificar o exercício do governo, reforçam a ideia que mesmo com eles, e apesar deles, o poder funciona, e com todo rigor, na "ponta extrema da sua racionalidade violenta" (Foucault, 2001: 17). Com isso, o seu efeito seria o da inevitabilidade de um governo.

Para uma formulação conceitual de liderança política seria profícua a sugestão de Foucault (2001: 15-17) sobre o funcionamento do "soberano infame". Se situarmos o problema da liderança política como um conjunto de mecanismos para fazer funcionar o governo e produzir efeitos de poder, o líder infame, grotesco, a autoridade ridícula e todos os graus do que se poderia nominar de

8 Em conversa com D. Trombadori, em Paris, no final de 1978, Foucault discorre longamente sobre sua trajetória intelectual, suas pesquisas, escolha dos temas e problemas e esclarece o que entende por crise de governo no presente.

9 Foucault empregou pela primeira vez o termo governamentalidade no curso de 1978, Segurança, Território e População, para designar o governo das condutas dirigido à população com os recursos da economia política e dos dispositivos de segurança (Foucault, 2008). Trata-se, portanto, de conceito construído para a análise do exercício do governo na época moderna. No curso de 1983, entretanto, Foucault (2010a: 148) emprega o termo governamentalidade no mesmo sentido de dynasteía, que diz respeito ao jogo político, das suas regras, dos seus procedimentos e do indivíduo que o exerce.

10 Seguimos aqui a análise da crise feita por José Luis Câmara Leme (2008: 181-197).

11 Além de uma gama de obras literárias sobre o grotesco do funcionário político em Kafka, Balzac, Dostoiévski e de governantes em Shakespeare. 
"indignidade do poder", passam a ser relevantes para a análise e formulação conceitual. Segundo o filósofo:

Mostrando explicitamente o poder como abjeto, infame, ubuesco ou simplesmente ridículo, não se trata, de limitar os seus efeitos (...). Parece [segundo o autor] que se trata, ao contrário, de manifestar da forma mais patente a incontornabilidade, a inevitabilidade do poder, que pode precisamente funcionar com todo rigor e na ponta extrema da sua racionalidade violenta, mesmo quando está nas mãos de alguém efetivamente desqualificado (Foucault, 2001:. 17).

Foucault (2010b), em conversa datada de 1978, como já mencionado anteriormente, refere-se à "crise de governo" no presente e a compara com a crise que provocou a dissolução da Idade Média. Seu intuito foi o de destacar um ponto de ruptura entre dois momentos históricos: um que termina e outro que se inicia e do qual nada se pode prever, pois o filósofo não arrisca nenhuma profecia. Será por meio da história, contudo, a partir de um problema posto no presente, que Foucault vai tomar distância do seu tempo e, assim, fazer a sua crítica. E, quiçá, contribuir para interceptar qualquer arranjo que restaure os mecanismos de governo vigente. Como dito por Foucault, não se deve propor solução para que ela "não nasça, de uma só vez, da cabeça de um intelectual reformador (...)” (Ibid.: 338). $\mathrm{O}$ autor, referindo-se às suas pesquisas e atuação política, recusa o lugar de porta-voz. Para ele, cabe aos agentes diretamente envolvidos o uso da palavra e da imaginação política. Isto porque os problemas arraigados na nossa vida cotidiana, como aqueles privilegiados em suas pesquisas - sexo, crime e loucura -, não são de fácil e rápida solução.

O trabalho intelectual consiste em situar-se no seu tempo e fazer um diagnóstico do presente, afirma Foucault ${ }^{12}$, não para justificá-lo ou reforçá-lo, mas para ultrapassá-lo. O intelectual situa-se nas fissuras do presente e as aprofunda

12 Cf. Foucault, 2000. Foucault retoma a reflexão de Kant de 1784 publicada em periódico alemão acerca da resposta à questão da Aufklärung. Afirma que essa reflexão inaugura uma "atitude de modernidade", descrita como um "modo de relação que concerne à atualidade; uma escolha voluntária que é feita por alguns; enfim, uma maneira de pensar e de sentir, uma maneira também de agir e de se conduzir (...) como aquilo que os gregos chamavam de êthos" (Ibid.: 342). Assim, a novidade da reflexão de Kant seria essa atitude de modernidade "como uma diferença na história e como motivo para uma tarefa filosófica particular" (Ibid.: 341). Nessa mesma direção, ver Agamben (2010). Com base em Nietzsche, Agamben define a contemporaneidade como uma singular relação com o tempo, que, na medida em que dele se aproxima, também dele toma distância (Ibid.: 59). Uma aderência a determinada época, em que se está envolvido, incapacita a reflexão crítica. Uma segunda definição de contemporâneo é a percepção na sua época não das luzes, mas do escuro (Ibid.: 62). 
impedindo que elas se reconstituam e se sedimentem. Como recurso metodológico à crítica do presente, o genealogista recorre à história para mostrar que ela é descontínua, e que determinados arranjos são a confluência de inúmeros acasos e encontros singulares irrepetíveis. Munido desse pensamento e movido pela crítica do presente, Foucault dá início a sua pesquisa da Antiguidade, interrompida por sua morte precoce.

Destacamos o seu curso de 1983, O governo de si e dos outros, em que o filósofo dedica-se, mais especificamente, ao problema da política, particularmente, à democracia direta dos atenienses, além da relação da filosofia com a política com base em Platão. Para desenvolver os temas-problemas selecionados, o autor, com certo ineditismo em relação aos estudiosos da Antiguidade, chama a atenção para o termo parresía, despercebido por eles. No curso de 1983, dedica-se ao estudo da parresía política, seja na democracia, seja na autocracia. Nesse último caso, irá destacar a ação do filósofo em relação à política.

\section{Uma interrogação sem fim da atualidade.}

Por atualidade entendemos, com base em Foucault, a interrogação do presente no qual nós fazemos parte e em relação ao qual devemos nos situar e precisar o campo das experiências possíveis (Foucault, 2010a: 21) ${ }^{13}$. O autor esclarece o sentido dado ao campo das experiências em suas pesquisas, desenvolvidas em três eixos, que ele reputa como a sua contribuição original, bem como traduzem deslocamentos ou descontinuidades na sua trajetória de pesquisa. $\mathrm{O}$ primeiro eixo foi o da formação dos saberes, não a partir de uma teoria do conhecimento, mas da materialidade própria dos discursos, das regras de enunciação e das formas de veridicção, ou seja, da verdade que é dita. O segundo eixo diz respeito à análise dos procedimentos e técnicas de governamentalidade. Trata-se do estudo do como o poder é exercido e dos seus efeitos na condução das condutas dos outros. Mais especificamente, consiste no estudo das tecnologias pelas quais uns governam os outros. $O$ terceiro eixo refere-se à constituição dos modos de subjetividade que não diz respeito ao traçado de uma historicidade dos seus diferentes modos de ser, mas da análise das diversas modalidades de sua produção com base nas técnicas de si consigo mesmo. Esse último eixo permitiu um deslocamento de sua pesquisa para a Antiguidade greco-romana.

13 Antes de estabelecer os objetivos do curso de 1983, Foucault retoma a questão posta por Kant em 1784 acerca do que é a Aufklärung. Essa questão situa a interrogação do filósofo no presente do qual toma parte e exige uma atitude crítica. Uma ontologia do presente ou de nós mesmos seria, para Foucault, o sentido político da interrogação filosófica. 
Grosso modo, temos: o eixo dos discursos, o eixo do governo ou governamentalidade e da sujeição, e o eixo da ética do sujeito e da liberdade.

Isto posto, cabe a seguinte questão: qual problema o presente põe para os objetivos desse estudo acerca da liderança política? Numa primeira formulação conceitual, pode-se situar a "liderança política" como um conjunto de procedimentos e tecnologias que visam ao comando das condutas de uns sobre os outros. Nesse caso, a liderança política seria conceituada, portanto, como tecnologia de governo. ${ }^{14}$

Situa-se esse estudo num problema do próprio presente que, grosso modo, se apresenta numa situação de crise, ou seja, as tecnologias e mecanismos da liderança política não funcionam mais, sem, contudo, outros virem a tomar o seu lugar. Abre-se uma fissura que possibilita novos experimentos. Nessa perspectiva metodológica, os estudos da democracia antiga são valiosos. Eles não visam ao resgate de nenhum modelo, mas ao modo de problematização da liderança política que na atualidade repercutiria numa nova conceituação. Para atingirmos esse objetivo, retomaremos a pesquisa de Foucault do termo grego parresía no seu sentido político.

Foucault dedicou-se nos dois últimos cursos, em 1983 e 1984, à genealogia da parresía. Particularmente no curso de 1983, ele objetiva ao estudo da parresía como procedimento de governo e, numa primeira tradução, como ao dizer-a-verdade o indivíduo se constitui como sujeito na relação consigo e com os outros (Foucault, 2010a: 42). Nessa dupla articulação do termo se divisa uma abordagem do governo com base num êthos.

Foucault coloca três questões que orientam o seu percurso para uma "ontologia dos discursos da verdade (ou veridicção)". A primeira refere-se à singularidade do modo de introduzir no real certo jogo de verdade. E essa pergunta exige que se considere o discurso da verdade como uma prática. A segunda diz respeito à invenção de um modo de ser do real com base na colocação do discurso de veridicção. Essa questão situa toda a verdade como um jogo de veridicção. E, por fim, a terceira alude ao modo de ser do sujeito condizente ao jogo da verdade. Essa última questão implica na noção de formas de subjetivação em sua relação com a noção de produção da subjetividade com base no ethos (Foucault, 2010a: 281).

14 Esse enunciado conceitual serve de orientação metodológica para uma pesquisa empírica que deverá precisar as tecnologias de comando empregadas pelo "líder" que assegura ao mesmo tempo o seu status político de liderança e o funcionamento do governo. Neste caso, o líder se apresenta dotado de capacidade de articulação política que resulta para si, seu estafe político e seguidores, sejam do seu partido, sejam de aliados, recursos próprios e um lócus de poder. 
Para definir parresía, Foucault opta, inicialmente, por dizer o que ela não é. Primeiro, não é um discurso que obedece a uma estrutura racional para a demonstração de uma verdade (Ibid.: 52). Segundo, não é uma técnica (tékhne) ou arte de persuasão pertencente à retórica (Ibid.: 53), porque essa não exige do discurso o compromisso com a veridicidade (uma das traduções de parresía). Terceiro, não se trata de uma pedagogia ou arte de ensinar (Ibid.: 54), por se tratar a parresía de uma fala franca, cortante, abrupta. Quarto, não é uma discussão (Ibid.: 55) porque não situa no terreno da controvérsia (erística) em que se busca fazer triunfar aquilo que se toma como verdadeiro.

A parresía também não pode ser apreendida como estratégia discursiva ou um enunciado performativo, ou seja, como dispositivo de poder ${ }^{15}$. Isto porque a parresía abre para aquele que pronuncia a verdade um "risco de vida" a partir do efeito desse discurso no interlocutor. Eis um dos elementos fundamentais do dizer-a-verdade, a coragem daquele que pronuncia o discurso verdadeiro. $\mathrm{E}$ nisso reside o seu sentido político: "a coragem da verdade".

0 risco que exige coragem por parte daquele que diz-a-verdade diferencia o discurso parresiástico de qualquer enunciado performativo que se pauta pelas seguintes características: primeira, codificação institucionalizada para o controle dos efeitos do discurso; segunda, autoridade do enunciador em razão do lugar institucionalizado que ocupa; terceira, a garantia pelo estatuto ocupado de que, ao emitir um enunciado, este se realize tal qual foi emitido.

Feitos todos esses senões, Foucault faz, no nosso entender, a melhor formulação conceitual do termo parresía:

A parresía (...) é portanto uma certa maneira de falar. Mais precisamente, é uma maneira de dizer a verdade. (...) Uma maneira de dizer a verdade tal que abrimos para nós mesmos um risco pelo fato de dizer a verdade. (...) A parresía é uma maneira de abrir esse risco vinculado ao dizer-a-verdade

15 Por dispositivo de poder Foucault entende três coisas: Primeiro, "Um conjunto decididamente heterogêneo que engloba discursos, instituições, organizações arquitetônicas, decisões regulamentares, leis, medidas administrativas, enunciados científicos, proposições filosóficas, morais, filantrópicas. Em suma, o dito e o não dito são elementos do dispositivo. O dispositivo é a rede que se pode estabelecer entre estes seguimentos. [Segundo], demarcar a natureza da relação que pode existir entre estes elementos heterogêneos. Sendo assim tal discurso pode aparecer como programa de uma instituição ou, ao contrário, como elemento que permite justificar e mascarar uma prática que permanece muda; pode ainda funcionar como reinterpretação dessa prática, dando-lhe acesso a um novo campo de racionalidade. (...) [Terceiro], o tipo de formação que em determinado momento histórico, teve como função principal responder a uma urgência. O dispositivo tem portanto uma função estratégica dominante" (Foucault, 1992: 244-246). O dispositivo é de natureza estratégica, mantendo relações de forças sustentadas por configurações de poder e tipos de saber. 
constituindo-nos de certo modo como parceiros de nós mesmos quando falamos, vinculando-nos ao enunciado da verdade e vinculando-nos à enunciação da verdade. Enfim, a parresía é uma maneira de se vincular a si mesmo no enunciado da verdade, de vincular livremente a si mesmo e na forma de um ato corajoso. A parresía é a livre coragem pela qual você se vincula a si mesmo no ato de dizer a verdade. Ou ainda a parresía é a ética do dizer-a-verdade em seu ato arriscado e livre. Nessa medida, para essa palavra parresía (...) poderemos (...) propor [como tradução] o termo "veridicidade". O parresiasta, aquele que utiliza a parresía, é o homem verídico, isto é, aquele que tem a coragem de arriscar o dizer-a-verdade e que arrisca esse dizer-a-verdade num pacto consigo mesmo, precisamente na medida em que é o enunciador da verdade. Ele é o verídico. (Foucault, 2010a: 63-64).

Essa conceituação descritiva tornar-se-á mais clara na medida em que Foucault analisar dois modos distintos de uso da parresía: primeiro, o uso político na democracia ateniense do séc. V a. C., por meio da peça Íon, do trágico Eurípides, e dos discursos de Péricles registrados pelo historiador Tucídides; segundo, o uso filosófico em textos de meados do séc. IV a. C. de Platão, com destaque para a Carta VII, em que o termo parresía aparece como uma função necessária à política, independente da forma da constituição (politeía). Nesse último caso, por meio da parresía se estabelece o vínculo do filósofo com a política. Retomaremos com mais detalhes, à frente, essa discussão. Por ora, gostaríamos de registrar o emprego político que, de acordo com a definição acima, confere ao discurso uma modalidade arriscada de atuação política que, na medida em que vincula o sujeito à verdade dita, o constitui na perspectiva do seu êthos. Eis uma nova formulação da relação entre a ética e a política com profundas repercussões na produção de um sujeito ético (no caso desse estudo, da liderança política) no seu exercício arriscado da liberdade pelo dizer-a-verdade.

Foucault diferencia o "discurso performativo", que é matéria para uma análise da "pragmática do discurso", do que ele vai denominar de "dramática dos discursos" referida à parresía. Enquanto, no primeiro, a situação real de quem fala afeta ou modifica o valor dos enunciados, na "dramática do discurso" parresiasta o enunciado e o ato de enunciação afetam e modificam o sujeito, porque aquele que diz algo se vincula ao fato de ter dito e é atingido pelos efeitos da verdade enunciada. Dobra-se a força da veridicidade sobre si, para a constituição de si próprio, ou melhor, deixa-se afetar no seu modo de ser como sujeito. É isso que Foucault denomina de subjetivação de si por si. 
Com base no exposto, podemos arriscar outra formulação conceitual para a liderança política em que está em jogo o êthos do sujeito da ação política. Bem diferente é o modo de subjetivação em que o sujeito é um produto dos dispositivos de poder e, ao mesmo tempo, contribui para o seu funcionamento. Trata-se, neste caso, de um assujeitamento.

As maneiras de se vincular como sujeito à verdade dita e se modificar na sua subjetividade podem ocorrer não somente por meio do discurso parresiasta do sujeito político, mas também do cientista, do filósofo, ou do profeta, desde que pronunciado fora dos vínculos institucionais ou contra eles. Isso porque os cientistas no interior das instituições científicas, os religiosos frente a sua instituição, como também os homens de partido, pronunciam o discurso da instituição a qual se prendem.

Frente ao exposto acerca da genealogia do discurso político, Foucault especifica o seu universo empírico. Destaca, inicialmente, a parresía política na peça Íon - apresentada no ano de 418 a. C. - que, para o autor, é uma peça "notável para expor a dramática do discurso verdadeiro" (Foucault, 2010a: 77). Nesse contexto, o governo se exercia pela dramática do dizer-a-verdade que, segundo Foucault, era denominada de aleturgia (manifestação da verdade por uma série de procedimentos ou governo pela verdade). Termo esse que torna indissociável o governo do êthos. O discurso de Péricles, registrado pelo historiador Tucídides, também irá constituir matéria empírica para a definição da parresía política, no contexto da liberdade democrática do século $\mathrm{V}$ a. C.

A parresía se define, tanto nos estudos da peça Íon como dos discursos de Péricles, como a fala mais alta em relação aos demais cidadãos e, também, sensata. Neste caso, trata-se de uma intervenção política, pela qual um homem, por meio do dizer-a-verdade, vai adquirir certa ascendência sobre os demais. Tal característica é que confere à palavra (logos) o poder na cidade em condições democráticas, porque assegura a liberdade de outras palavras num jogo político agonístico (disputa ou luta). É, portanto, pela palavra que o poder se exerce na polis democrática. E, mais, é pela parresía que um cidadão assume ascendência política sobre os demais. (Foucault, 2010a: 97-98).

A obediência política na democracia está vinculada ao exercício da palavra que persuade os demais comandados, numa disputa em que está assegurada a liberdade de outros também comandarem pela persuasão. A parresía se circunscreve nesse jogo político agonístico, no qual não se dobra o outro pela vontade, mas, sim, pelo convencimento (Ibid.: 98). Porém, diferentemente da arte retórica, essa persuasão se dá por meio da introdução no jogo político da coragem 
da verdade, o uso da palavra franca - parresía, que coloca seu protagonista num duplo risco, de desagradar a multidão e da hostilidade dos demais oradores.

Antes de iniciar a análise da peça trágica Íon, Foucault revela a procedência de seu interesse em pesquisar o sentido de parresía na democracia. E este decorre da definição de democracia de Políbio (apud Foucault, 2010a: 139). Para esse historiador da República romana (séc. III a C.), a democracia é a forma de governo (politeía) que se caracteriza por duas noções, a isegoria e a parresía. Por que ele privilegiou apenas essas duas noções? Qual a diferença entre elas? Sabe-se que a isegoria refere-se à igualdade de direito à palavra, nos tribunais, nas tomadas de decisão nas assembleias, nas escolhas dos integrantes das funções públicas.

Foucault destaca a peça Íon (418 a. C.) para tentar precisar o sentido de parresía. Dentre os diferentes rituais de veridicção (manifestação da verdade) nesta peça, Eurípides denomina de parresía somente aquele que se refere à busca de Íon pelo direito político de exercer na sua cidade o poder pelo dizer-a-verdade. Para isso, ele precisa saber quem é a sua mãe, pois essa é a condição para que ele possa retornar a Atenas e fundar a democracia. "A parresía é que vai ser na pessoa de Íon o fundamento da democracia" (Foucault, 2010a: 144). De acordo com Foucault, existiria uma circularidade essencial entre parresía e democracia. “(...) para haver democracia é preciso haver parresía; para haver parresía, é preciso haver democracia" (Ibid.).

Esse caráter indissociável entre a parresía e a democracia significa que o uso da parresía como a fala franca, o dizer-a-verdade, pressupõe a constituição da cidade (politeía) que assegure o direito à palavra, a isegoria, que é constitutivo da cidadania. Mas a parresía é algo diferente de isegoria. Afirma Foucault:

[A Parresía] é um elemento que, no interior desse âmbito da politeía democrática que dá a todos o direito de falar, permite que os indivíduos adquiram certa ascendência uns sobre os outros (...). A isegoria define simplesmente o marco constitucional em que a parresía vai atuar como sendo livre e, consequentemente, corajosa atividade de alguns que se adiantam, tomam a palavra, tentam persuadir, dirigem os outros, com todos os riscos que isso comporta. (2010a: 147).

Com o sentido posto anteriormente de parresía no interior de uma constituição democrática, podemos formular um enunciado de liderança política. Por liderança política entendemos alguém que assume ascendência sobre os demais e exerce o comando sobre eles pelo uso da palavra franca com todos os riscos que isso comporta. 
Tucídides refere-se a Péricles, no momento de sua aparição na cena política, como um autêntico líder político dos atenienses, ou "o primeiro entre os atenienses, o que maior força tinha no falar e no agir” (Tucídides, 2013: 197). No relato do seu discurso em que aconselha os atenienses à recusa das imposições dos peloponésios (espartanos), advertindo sobre os riscos dessa decisão e da inevitabilidade de se escapar da guerra, Péricles se expõe em e para o público, cuja decisão envolve a todos. A liderança age com e pelo interesse comum ${ }^{16}$. Existe, entre líderes e liderados, uma relação de confiança medida pelas provas que ele dá na sua trajetória política. Constitui, portanto, a confiança (pistis) recíproca dos cidadãos entre si - não se pode esquecer que o líder é também um cidadão -, um elemento da subjetividade que assegura o bom exercício da democracia.

Foucault chama a atenção para a diferença entre politeía como marco constitucional que define os direitos dos cidadãos e a dynasteía, que designa o "exercício do poder (...), ou o jogo pelo qual o poder se exerce efetivamente numa democracia" (Foucault, 2010a: 147). Numa democracia, esse exercício se dá pela ascendência de alguns cidadãos sobre outros por meio do discurso que persuade. Assim posto, a dynasteía diz respeito ao problema da qualidade do personagem, em sua relação consigo e com os outros, no que ele é em seu êthos. A parresía seria o elo entre a condição formal, a politeía, e o exercício efetivo da política, a dynasteía, incluindo suas regras, seus procedimentos e o indivíduo que o exerce. Nada mais equívoco do que confundir-se a política com $o$ político: ou seja, a atividade política, que define as relações consigo e com os outros, com o aspecto formal do poder político. Trata-se, pois, a política de um exercício de governo (a ascendência política de uns sobre os outros) pela palavra franca, pelo dizer-a-verdade e com a coragem em meio à relação agonística - na luta, na disputa, na liça.

Em suma, eis os quatro vértices do retângulo da parresía apontado por Foucault. O vértice constitucional ou formal da democracia, a isegoria, que garante a todos os cidadãos a igualdade de falar, opinar e participar das decisões públicas. Segundo, o vértice do jogo político, a dynasteía, a condição do exercício efetivo do governo, na qual se dá a ascendência e superioridade de alguns. Terceiro, o vértice da verdade ou o dizer-a-verdade, isto é, a necessidade de um

16 Na atualidade, a liderança política no sentido forte do termo é atribuída àqueles que catalisam mudanças sociais e lutam com e pelo interesse daqueles que comanda, numa situação de enfretamento de posições divergentes e conflitantes. 
logos sensato. Quarto, o vértice da coragem, em meio à luta, num discurso que disputa a supremacia com outros numa relação agonística.

O bom funcionamento da parresía com a democracia foi exposto por Tucídides em sua obra História da Guerra do Peloponeso, em referência aos discursos de Péricles ${ }^{17}$. Este, ao pronunciar seu "Discurso da Guerra", utiliza um direito constitucional dado a todo cidadão do uso da palavra (isegoria). Ele pronuncia um discurso que reivindica para si mesmo e o qual se identifica, ou seja, um discurso da verdade pela qual conquistou a ascendência sobre os demais cidadãos. Péricles refere-se às possibilidades de sucesso e de fracasso, expondo-se ao risco de dizer-a-verdade em público em meio à luta. O "pacto parresiástico" celebrado em público com todos os cidadãos reunidos em Assembleia (Ecclesia) se dá nos seguintes termos: Péricles diz a verdade e os aconselha, mas se aceitarem, todos serão solidários nas consequências (Foucault, 2010a: 161-163). Mais tarde, quando este pacto foi rompido, Péricles arrisca-se ao pronunciar o que ficou conhecido por Tucídides como o "Discurso da Peste", contrariando o povo e fazendo-lhes críticas.

Segundo Foucault, nos discurso de Péricles, tal qual relatado por Tucídides, divisam-se as qualidades de um parresiasta para o exercício, por meio de sua parresía, da ascendência política sobre os demais cidadãos, a fim de tornar a democracia governável. São as seguintes essas qualidades: ser verdadeiro, ser capaz de dizer-a-verdade, ser dedicado ao interesse geral, ser moralmente íntegro, ou seja, não ser corruptível (Foucault, 2010a: 165).

A democracia torna-se governável em razão do discurso verdadeiro. Foucault vai empregar o termo governamentalidade num sentido largo para designar o exercício do poder, conforme sua afirmação que "a emergência do discurso verdadeiro, está na própria raiz do processo de governamentalidade" (Ibid.: 169). Cabe frisar que, mais do que definir um método para cunhar os conceitos e, posteriormente, fixá-los em modelos, Foucault os constrói e os emprega em contextos históricos específicos. Daí, em razão de seu procedimento genealógico, a variabilidade de sentidos que eles assumem, que em nada tem a ver com a falta de rigor ou imprecisão do autor.

Retomando as razões da governamentalidade da democracia ou exercício imanente do poder, Foucault destaca dentre elas a parresía. É por essa última que se cria uma distinção no seio da igualdade democrática. E mais, essa

17 Trata-se dos seguintes discursos pronunciados por Péricles, em distintos momentos, na Assembleia dos cidadãos atenienses (Ecclesia): o "Discurso da guerra", o "Discurso aos mortos na Guerra do Peloponeso" e o "Discurso da peste". 
distinção não se reveste em ameaça ao seu funcionamento, enquanto for possível a emergência de uma liderança política com as qualidades acima citadas, que Tucídides atribuiu a Péricles. Cabe ressaltar que o termo liderança política, em uma das possibilidades de conceituação adotada nesse estudo, concebe a atuação política com base numa relação política que privilegia o êthos do personagem, no caso, a coragem da verdade.

Em meados do século IV a. C., aprofundam-se os paradoxos presentes na relação entre democracia e parresía. O exercício desse governo se corrompe e abre-se um flanco para a crítica da filosofia. Foucault destaca dois paradoxos da democracia, são eles: primeiro, o vínculo inseparável entre a parresía e a democracia, mas esse discurso verdadeiro promove uma diferença na igualdade democrática; segundo, embora não exista democracia sem discurso verdadeiro, a própria democracia, na medida em que opera na disputa, no enfrentamento e no conflito, ameaça o discurso verdadeiro (Foucault, 2010a: 169-170).

O uso da palavra na democracia torna-se alvo de críticas no teatro, por meio da comédia, e, também, pelos filósofos. O discurso parresiástico não mais promove a ascendência de uma liderança qualificada por seu êthos da coragem da verdade ou parresía. Aqueles que fazem uso do direito à palavra utilizam-na para a defesa da opinião da maioria. Falta-lhes a coragem para contrariar a opinião corrente e, por isso, eles agem como bajuladores ou lisonjeadores, empreendendo um discurso demagógico. Os oradores dedicam-se a agradar a maioria em detrimento de um interesse público. Para Platão, a liberdade da palavra na democracia, ou melhor, o excesso dessa liberdade, em que todos podem dizer o que quiserem, estaria na origem da demagogia que corrompe essa forma de constituição (politeía) ${ }^{18}$. A liberdade da palavra se dissocia, nesse caso, da parresía, que não é simplesmente essa liberdade, mas é a franqueza ou a "profissão de verdade" que consiste na prática política efetiva que servirá de guia de uns pelos outros (Foucault, 2010: 171). O parresiasta difere, portanto, do demagogo, cuja etimologia é guia do povo.

Se a parresía na peça Íon de Eurípides articulava-se com a democracia, como também na própria definição de Políbio, em Platão essa noção de parresía

18 Foucault (2010: 168) destaca a crítica de Isócrates em seu “Tratado sobre a Paz". Platão, no livro VIII da República (s/d), empreende uma crítica arrasadora da democracia. Por meio do seu método, analisa sucessivos estágios de corrupção das formas de governo à luz de um Modelo Ideal de constituição (politeía) e de virtudes da alma ( $p s y k h e ́)$ que compõem o caráter (êthos) do homem. Numa escala descendente de corrupção, a democracia ocupa o penúltimo lugar, abaixo da oligarquia e acima da tirania e, mais ainda, é da própria democracia que se origina a tirania. A cidade democrata, em razão do excesso de liberdade que corrompe a educação pelas virtudes, faz surgir os "demagogos" ou, nas palavras de Platão, os ambiciosos de poder e aduladores do povo (Platão, s/d: 400-401). 
política sofre um deslocamento e terá lugar em outros regimes, dentre eles, a autocracia. Mas o sentido muda, pois a parresía constituiria na coragem de desafiar o governante. Foucault destaca a Carta VII de Platão, em que o filósofo relata a sua experiência política parresiasta junto ao tirano de Siracusa. O tipo de atuação política do filósofo na corte do tirano Dionisio se diferencia do exercício direto na política perante uma assembleia, aconselhando os cidadãos na tomada de decisão. Trata-se, contudo, de uma parresía, um dizer-a-verdade que aceita correr o risco do perigo que implica na livre interpelação da conduta do governante. Nesse caso, o filósofo tenta interferir na política por meio do conselho àquele que governa, arriscando contrariá-lo pelo uso da fala franca ou parresía.

Segundo Gros, por meio da análise da Carta VII de Platão, Foucault vai situar o próprio empreendimento filosófico. $\mathrm{O}$ ineditismo da análise de Foucault sobre Platão está no privilégio da atuação diretamente política desse filósofo. Trata-se de uma relação de exterioridade à política, diferindo da abordagem do diálogo República. Nesse último, Platão constrói um Modelo Ideal de cidade justa e de homem justo e atribui o governo ao rei-filósofo, cuja legitimidade advém do conhecimento e da prática desse Modelo.

Foucault, ao colocar em evidência a análise da Carta VII, pretende afirmar, segundo Gros (2010:348), que "a atividade filosófica não deve se confinar apenas ao discurso, mas colocar-se à prova das práticas, dos conflitos e dos fatos. $\mathrm{O}$ real da filosofia será encontrado nesse confronto ativo com o poder". E mais, Foucault também questiona a figura do rei-filósofo, e, na análise de outros diálogos de Platão, vai revelar que o que está em jogo não é o conhecimento que o governante detém, mas "um modo de ser, uma relação de si consigo mesmo" (Gros, 2010: 350). Eis mais uma contribuição original de Foucault para o debate atual acerca da relação entre filosofia e política que difere dos dispositivos de saber-poder.

\section{Para finalizar...}

Na primeira abordagem conceitual da liderança política confrontamos dois pensadores, Maquiavel e Foucault, particularmente, como base na formulação de dois conceitos, parresía e virtù. Priorizamos esses conceitos por tratar-se de atributos que conferem destaque ao exercício da política articulada à atividade da liderança.

Considerando a diferença nas abordagens e o contexto histórico em que os conceitos foram formulados, entendemos que ambos conferem relevância ao sujeito da ação política. Este atua em meio às relações de conflito, de luta e disputas que exigem daqueles que se pretendem à liderança o protagonismo 
nas lutas sem garantias prévias. Comum a ambos é a ausência da soberania do Estado. Tanto a virtù quanto a parresía estão na proveniência, exercício e continuidade do poder político.

Por se tratar de uma qualidade política da liderança, a parresía e a virtù são adquiridas e perdidas em meio à luta. A virtù, segundo Maquiavel, se mede numa relação com a fortuna, não podendo, portanto, ser ensinada ou reduzida a uma qualidade inata de alguém. Isto porque as circunstâncias são mutáveis, exigindo dos protagonistas uma contínua adequação das ações.

A partir de um problema da atualidade, divisamos duas linhas conceituais distintas: a primeira, na época moderna, a liderança como uma tecnologia de poder ou, mais especificamente, de governo. Nesse caso, privilegia-se a análise das técnicas, procedimentos e mecanismos utilizados para o governo das condutas de uns sobre os outros. A liderança política seria parte dessa engrenagem e a qualidade dessa liderança se mesura por meio do bom funcionamento dessa relação de poder.

A segunda linha conceitual situa, num primeiro momento, o vínculo entre democracia e parresía. A liderança política seria, no seio da democracia, um elemento de ascendência política pelo uso da fala franca, o dizer-a-verdade em público e para o público detentor dos direitos de cidadania os quais dizem respeito à tomada de decisões nas assembleias, participação nos tribunais e ocupação de funções públicas. A parresía situa-se em meio ao jogo agonístico. A liderança não se dissocia do seu êthos da coragem da verdade. O sujeito identifica-se com a verdade que pronuncia. O líder político utiliza o privilégio da liberdade da palavra para, com sua coragem da verdade, comandar os outros. A palavra franca exige coragem e expõe aquele que a pronuncia ao risco, numa democracia, de desagradar à opinião da maioria.

Um deslocamento da parresía política se dá com os críticos da democracia, em meados do século IV a. C., que acusam essa forma de governo de prevalência da fala demagógica, ou de um uso retórico ${ }^{19}$ sem compromisso com a veridicidade ou parresía. Sócrates, Platão, Xenofonte e outros filósofos antigos se posicionam criticamente em relação ao exercício da política na democracia. A coragem da verdade, com eles, não se faz no interior do campo político, mas como crítica externa ou em relação às instituições políticas, e não nas instituições políticas.

19 Caberia uma discussão a respeito do uso da retórica como recurso político para influenciar e guiar os outros para a tomada de decisões na Antiguidade. Assim como, na atualidade, o emprego do marketing político na construção da imagem da liderança política. 
Sócrates percorre as ruas incitando, com seu método, qualquer um, seja cidadão ou não, ao cuidado de si. E a filosofia antiga e o filósofo se apresentam autênticos (étymos) agentes da parresía. Isto porque uma vida filosófica caracteriza-se por um modo de vida que é em si mesmo a manifestação da verdade. Viver filosoficamente é procurar mostrar, pelo êthos, a maneira como se vive.

Em relação à política com base nesse êthos filosófico, no caso a parresía, o filósofo interpela a conduta dos que governam com todo o risco implicado. Várias foram as maneiras, na Antiguidade greco-romana, de dirigir-se aos que governam: desde a educação dos príncipes (estóicos), passando pela insolência dos cínicos, até os círculos de oposição ao poder (epicuristas). Mas, com suas pesquisas sobre os diferentes estilos de vida filosófica e de relação com a política, Foucault afirma a atualidade de um modo de ser filosófico, como veridicção ou parresía.

Para concluirmos, afirmamos a pertinência para este estudo da liderança política desse modo de colocação do problema: uma crítica com base no êthos, ou seja, uma maneira de pensar e de sentir, um modo de agir e de se conduzir. Seguindo as sugestões de Foucault, entendemos ser importante construir linhas de pesquisa em torno da ética do sujeito ou dos modos de produção da subjetividade na perspectiva da atividade política.

Em suma, podemos distinguir dois grandes blocos de abordagem conceitual da liderança política. No primeiro bloco podemos reunir diferentes atuações políticas de liderança, tendo como diferencial a ascendência de uns sobre os outros, pelos seguintes fatores: dar início a algo novo, a fundação de novas instituições e arranjos políticos, catalisar grandes mudanças sociais; um êthos expresso na coragem da verdade no enfretamento dos que governam, pondo em risco sua vida. Essa opção teórico-metodológica é profícua em razão de seu sentido aberto ao contexto histórico que inclui também os fluxos do pensamento e do agir segundo os valores a serem adotados.

No segundo bloco estão os líderes como efeitos do dispositivo de poder que, por sua vez, fazem com que esses mecanismos funcionem. Cumpre salientar que essas tecnologias não são estruturas generalizáveis que se aplicam igualmente em diferentes contextos históricos. Ao contrário, elas exigem um minucioso estudo descritivo de seu funcionamento, elas sofrem mutações e têm uma história descontínua. Tais lideranças podem variar numa escala que vai do tipo grotesco ao governante burocrata. Um mesmo personagem poderá, em determinado contexto e momento da história, se configurar como liderança que afronta os próprios mecanismos de governo e tornar-se, em outro momento, um líder que faz funcionar esses mesmos mecanismos. 
A parresía (a fala franca, o dizer-a-verdade) se configurou, na Antiguidade, na diferença ética na constituição da subjetividade da liderança política. Disso decorre a distinção entre ética e moral. Esta última baseia-se na observância de um código moral, cabendo aos indivíduos, tal como são, obedecê-lo. Não existe um comprometimento com aquilo que se faz e com o que se fala, pois a obediência a um código moral imposto por um externo degrada a subjetividade em sujeição. Já a ética implica na construção de regras facultativas e mutáveis segundo as circunstâncias. Foucault insiste na articulação da ética com uma estética da existência. No sentido da política, a parresía é um procedimento que caracteriza o exercício da democracia na Antiguidade, como também, uma conduta da filosofia antiga em relação à política.

Retomando a ideia inicial que motivou este artigo, concluímos ser o conceito de parresía política, seja como atitude de resistência às formas autocráticas de governo, seja na democracia como exigência de compromisso ético das lideranças, significativo para entendemos que essa noção política traria importante contribuição para o debate atual e o enfrentamento da crise da liderança política. O pensamento político moderno e contemporâneo conferiu especial atenção ao conceito de virtù de Maquiavel. Entendemos que a sugestão de Foucault poderia mobilizar a discussão contemporânea acerca da liderança política.

\section{Referências}

AGAMBEN, Giorgio. O que é o contemporâneo? e outros ensaios. Trad. Vinícius Nicastro Honesko. Chapecó: Argos, 2010.

ARENDT, H. A condição humana. Trad. Roberto Raposo. Rio de Janeiro: Editora Forense, $9^{a}$ Edição, 1999.

BERLIN, I. Introdução: A originalidade de Machiavelli, em MACHIAVELLI, Nicolo. $O$ Príncipe. Trad. Lívio Xavier. Rio de Janeiro: Ediouro Publicações, 2000.

BURCKHARDT, J. A cultura do Renascimento na Itália. Trad. Sérgio Tellaroli. São Paulo, Companhia das Letras, 1991.

CASTORIADIS, Cornelius. A polis grega e a criação da democracia. In: As encruzilhadas do labirinto/2. Trad. José Oscar de Almeida Marques. Rio/São Paulo: Paz e Terra, 1987.

EDMOND, M-P. Maquiavel. In : CHATELET, F., DUHAMEL, O., PISIER, E. (Orgs.)

Dicionário das obras políticas. Rio de Janeiro: Civilização Brasileira, 1993.

FINLEY, Moses. Líderes e liderados. In: Democracia antiga e moderna. Trad. Waldéa

Barcellos. Rio de Janeiro: Graal, 1988.

FOUCAULT, Michel. O governo de si e dos outros. Trad. Eduardo Brandão. São Paulo:

Martins Fontes, 2010a. 
FOUCAULT, Michel. Conversa com Michel Foucault. In: MOTTA, Manoel Barros da (Org.). Ditos e Escritos VI. Rio de Janeiro: Forense Universitária, 201ob.

FOUCAULT, Michel. Segurança, território, população. Trad. Eduardo Brandão. São Paulo: Martins Fontes, 2008.

FOUCAULT, Michel. Política e ética: uma Entrevista. In: MOTTA, Manoel Barros da (Org.). Ditos e Escritos V. Rio de Janeiro: Forense Universitária, 2004.

FOUCAULT, Michel. Os anormais. Trad. Eduardo Brandão. São Paulo: Martins Fontes, 2001.

FOUCAULT, Michel. O que são as luzes? In: MOTTA, Manoel Barros da (Org.). Ditos e Escritos II - Arqueologia das ciências e história dos sistemas de pensamento. Rio de Janeiro: Editora Forense Universitária, 2000.

FOUCAULT, Michel. Sobre a história da sexualidade. In: MACHADO, Roberto (org.). Microfísica do poder. $10^{a}$ edição. Rio de Janeiro: Graal, 1992.

FOUCAULT, Michel 1992a. Nietzsche, a genealogia e a história. In: MACHADO, Roberto (org.). Microfísica do poder. 10 a edição. Rio de Janeiro: Graal, 1992a.

GROS, Frédéric. Situação do curso. In: FOUCAULT, Michel. O governo de si e dos outros. Trad. Eduardo Brandão. São Paulo: Martins Fontes, 2010.

LEME, José Luis Câmara. A crise da governamentalidade e o poder ubuesco. In: ALBUQUERQUE, Durval Muniz de; VEIGA-NETO, Alfredo; SOUZA, Alípio de (orgs.). Cartografias de Foucault. Belo Horizonte: Autêntica, 2008.

MACHIAVELLI, Niccolò. O Príncipe. Trad. Lívio Xavier. Rio de Janeiro: Ediouro Publicações, 1992.

MAQUIAVEL, Nicolau. Comentários sobre a Primeira Década de Tito Lívio. Trad. Sérgio Bath. Brasília: UnB, 1979.

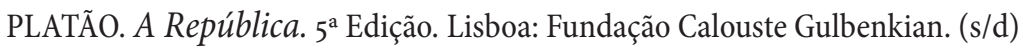

SCHUMPETER, J. A. Capitalismo, socialismo e democracia. Trad. Sérgio Goés de Paula. Rio de Janeiro: Zahar, 1984.

TÓTORA, Silvana. A questão democrática: perspectivas teóricas e análise do pensamento político brasileiro da década de 1980. Tese de doutorado em Ciências Sociais - concentração em política. Pontifícia Universidade Católica de São Paulo, 1998.

TUCÍDIDES. História da guerra do Peloponeso. Livro I. Trad. Anna Lia Amaral de Almeida Prado. $3^{\text {a }}$ edição. São Paulo: Martins Fontes, 2013.

WEBER, Max. Parlamentarismo e governo numa Alemanha reconstruída. Trad. Maurício Tragtenberg. In: Os Pensadores. São Paulo: Abril Cultural. WEBER, Max (1979). A política como vocação. In: GERTH \& WRIGHT MILLS (orgs). Max Weber. Trad. Waltensir Dutra. $4^{\mathrm{a}}$ Edição. Rio de Janeiro: Zahar, 1974. 
Recebido em 18/04/2016

Aprovado em 20/05/2016

\section{Como citar este artigo:}

TÓTORA, Silvana Maria Corrêa; CHAIA, Miguel. Liderança Política: Virtù e Parresía.

Contemporânea - Revista de Sociologia da UFSCar, v. 6, n. 2, jul.-dez. 2016, pp. 389-412. 